\title{
Morphoagronomic and molecular characterization of ornamental passion fruit cultivars
}

\author{
Kenia Gracielle da Fonseca(1), Fábio Gelape Faleiro(2), \\ Nilton Tadeu Vilela Junqueira ${ }^{(2)}$, Mariana Barth ${ }^{(3)}$ and Nelson Pires Feldberg ${ }^{(4)}$
}

\begin{abstract}
(1)Universidade de Brasília, Faculdade de Agronomia e Medicina Veterinária, Campus Universitário Darcy Ribeiro, CEP 70910-900 Brasília, DF, Brazil. E-mail: kenia.gfonseca@gmail.com ${ }^{(2)}$ Embrapa Cerrados, BR-020, Km 18, Caixa Postal 08223, CEP 73010-970 Planaltina, DF, Brazil. E-mail: fabio.faleiro@embrapa.br, nilton.junqueira@embrapa.br (3)União Pioneira de Integração Social, SEPS 712/912, Conjunto A, Asa Sul, CEP 70390-125 Brasília, DF, Brazil. E-mail: marianabarth3@gmail.com ${ }^{(4)}$ Embrapa Produtos e Mercado, Escritório de Canoinhas, BR-280, Km 231, no 1.151, Industrial II, Caixa Postal 317, CEP 89460-000 Canoinhas, SC, Brazil. E-mail: nelson.feldberg@embrapa.br
\end{abstract}

\begin{abstract}
The objective of this work was to validate the morphoagronomic descriptors used in the protection processes of plant cultivars in Brazil, by characterizing six cultivars of ornamental passion fruit. The BRS Rubiflora, BRS Rosea Púrpura, BRS Céu do Cerrado, BRS Roseflora, BRS Estrela do Cerrado, and BRS Pérola do Cerrado cultivars, 33 morphoagronomic descriptors, and two molecular markers were used. The categorical morphoagronomic descriptors were analyzed by frequency distribution and multivariate analyses. The quantitative morphoagronomic descriptors were subjected to the analysis of variance and to the comparison of the means of each cultivar. The random amplified polymorphic DNA (RAPD) and the inter-simple sequence repeats (ISSR) markers were used for molecular analysis. A high-validation rate was observed for the morphoagronomic descriptors used in the protection of plant cultivars. The analyses of variance showed significant differences between the quantitative descriptors, and the molecular markers confirmed the genetic differences among the cultivars. There was a high correlation between the calculated distances based on the categorical morphoagronomic descriptors and molecular markers. The morphoagronomic descriptors and molecular markers are useful and complementary for the characterization and differentiation of cultivars.
\end{abstract}

Index terms: Passiflora, molecular markers, multivariate analysis, plant cultivar protection.

\section{Caracterização morfoagronômica e molecular de cultivares de maracujazeiro ornamental}

Resumo - O objetivo deste trabalho foi validar os descritores morfoagronômicos utilizados nos processos de proteção de cultivares no Brasil, por meio da caracterização de seis cultivares de maracujazeiro ornamental. As cultivares BRS Rubiflora, BRS Rosea Púrpura, BRS Céu do Cerrado, BRS Roseflora, BRS Estrela do Cerrado e BRS Pérola do Cerrado, 33 descritores morfoagronômicos e dois marcadores moleculares foram utilizados. Os descritores morfoagronômicos categóricos foram analisados por meio da distribuição de frequência e análises multivariadas. Os descritores morfoagronômicos quantitativos foram submetidos à análises de variância e à comparação entre médias das cultivares. Os marcadores "random amplified polymorphic DNA" (RAPD) e "inter-simple sequence repeats" (ISSR) foram usados para análise molecular. Observou-se alta taxa de validação dos descritores morfoagronômicos utilizados na proteção de cultivares. As análises de variância mostraram diferenças significativas entre os descritores quantitativos das cultivares, e os marcadores moleculares confirmaram as diferenças genéticas entre elas. Houve alta correlação entre as distâncias calculadas com base nos descritores morfoagronômicos categóricos e nos marcadores moleculares. Os descritores morfoagronômicos e os marcadores moleculares são úteis e complementares para a caracterização e a diferenciação das cultivares.

Termos para indexação: Passiflora, marcadores moleculares, análise multivariada, proteção de cultivares.

\section{Introduction}

The production chain system of flowers and ornamental plants contributed R $\$ 4.5$ billion to the Brazilian gross domestic product (GDP) in 2014 representing $0.6 \%$ of the agricultural GDP), and the main per capita consumers were from São Paulo state, Distrito Federal, and Rio Grande do Sul state (Neves \& Alves Pinto, 2015; Ibraflor, 2016). 
Although Passiflora with ornamental potential have been cultivated for this purpose for more than a century in various countries, in the Northern Hemisphere (Peixoto, 2005), only recently it has been used as ornamental plants in Brazil, after Embrapa, in partnership with some other organizations, started producing some hybrids (Cerqueira-Silva et al., 2014). In 2007, the first ornamental hybrids - 'BRS Estrela do Cerrado', 'BRS Roseflora', and 'BRS Rubiflora' were launched and, in 2013, 'BRS Pérola do Cerrado' was also launched. Besides its ornamental potential, 'BRS Pérola do Cerrado' shows other aptness, such as its consumption in natura, industrial processing, and functional property (BRS Pérola..., 2015; BRS Estrela..., 2016; BRS Roseflora..., 2016; BRS Rubiflora..., 2016).

An organized system for the production and commercialization of seed and seedlings is necessary, in order to make developed cultivars by genetic breeding programs reach the producers and benefit all the supply chain. To accomplish this, cultivars should be registered at Registro Nacional de Cultivares (RNC), a department of the Ministério da Agricultura, Pecuária e Abastecimento (Mapa). Besides being registered, cultivars should also be protected by Serviço Nacional de Proteção de Cultivares (SNPC), the national service for cultivar protection, also of Mapa. In this case, the cultivars should be a result of genetic breeding and meet the criteria of distinctness, uniformity, and stability (DUS) that are verified through minimum descriptors (Jesus et al., 2015, 2016; Brasil, 2016). In 2008, the SNPC published the official guidelines for DUS testing to assess the wild cultivar species and interspecific hybrids of Passiflora, including a list of 33 morphoagronomic descriptors that was reviewed in 2016. A safe and efficient use of those guidelines requires an experimental validation with several known cultivars, in order to establish standard cultivars, which is essential to bring balance to the methodologies, in different regions, and by distinct evaluators (Brasil, 2016).

The cultivar characterization and the verification of genetic diversity can be performed based on morphoagronomic descriptors and by using molecular markers. Studies on the characterization of genetic diversity using the morphological and agronomic characteristics of Passiflora have been reported in the literature (Araújo et al., 2008; Santos et al., 2011a; Machado et al., 2015). Other studies have also been carried out by associating molecular markers (Viana et al., 2010).
The objective of this work was to validate the morphoagronomic descriptors used in protection processes of plant cultivars in Brazil, by characterizing six cultivars of ornamental passion fruit.

\section{Materials and Methods}

The ornamental passion fruit cultivars BRS Rubiflora, BRS Rosea Púrpura - BRS RP, BRS Roseflora, BRS Céu do Cerrado, BRS Estrela do Cerrado, and BRS Pérola do Cerrado were characterized according to the guidelines specified for DUS published in 2008, which are part of a list with 33 morphoagronomic descriptors, proposed by the Brazilian plant cultivar protection office (SNPC-Mapa) for wild and interspecific hybrid species of Passiflora (Brasil, 2016). Such descriptors, which had already been determined when plant cultivar protection was requested, were obtained once again for the validation process, considering the morphological characterization performed in different periods of time or locations. Evaluations were made in 2014 and 2015, in representative units, and at the Flor da Paixão active germplasm bank, except for 'BRS Pérola do Cerrado', which was analyzed at the experimental field $\left(15^{\circ} 35^{\prime} \mathrm{S}\right.$, $47^{\circ} 42^{\prime} \mathrm{W}$ ), all sites located at Embrapa Cerrados, in Planaltina, DF, Brazil.

The cultivars used for the tests resulted from genetic breeding programs performed by Embrapa Cerrados. 'BRS Estrela do Cerrado' is a hybrid resulting from the crossing between two wild species: Passiflora coccinea (red flower) and Passiflora setacea (white flower). 'BRS Rubiflora' and 'BRS Roseflora' hybrids are backcrosses between 'BRS Estrela do Cerrado' and P. coccinea and P.setacea, respectively (Faleiro et al., 2009). BRS Pérola do Cerrado is a cultivar from wild passion fruit, and it is a result of a mass selection of populations obtained by using several accessions of P. setacea (BRS Pérola..., 2015). The crosses for 'BRS Rosea Púrpura' obtention involved three wild species of Passiflora (P.quadrifaria, P.setacea and P.incarnata), while 'BRS Céu do Cerrado' was obtained from the crossing between $P$. incarnata and P. edulis (that was backcrossed with P.edulis).

The group of 33 morphoagronomic descriptors (19 qualitative/pseudo-qualitative, and 14 quantitative) is constituted of 11 descriptors related to the branch, leaf blade and petiole, 12 are related to flowers, and 10 are fruit characteristics (Table 1). Qualitative 
Table 1. Characteristics (descriptors) and frequency distribution based on the percentage of the phenotypical class of each descriptor, considering 24 branches, leaves, flowers, and fruits evaluated for the passion fruit (Passiflora spp.) ornamental cultivars BRS Estrela do Cerrado, BRS Rubiflora, BRS Roseflora, BRS Céu do Cerrado, BRS Rosea Púrpura, and BRS Pérola do Cerrado.

\begin{tabular}{|c|c|c|c|c|c|c|c|}
\hline Descriptor & Identification of the characteristics & $\begin{array}{l}\text { BRS Estrela } \\
\text { do Cerrado }\end{array}$ & $\begin{array}{c}\text { BRS } \\
\text { Rubiflora }\end{array}$ & $\begin{array}{c}\text { BRS } \\
\text { Roseflora }\end{array}$ & $\begin{array}{l}\text { BRS Céu do } \\
\text { Cerrado }\end{array}$ & $\begin{array}{l}\text { BRS Rosea } \\
\text { Púrpura }\end{array}$ & $\begin{array}{l}\text { BRS Pérola } \\
\text { do Cerrado }\end{array}$ \\
\hline 1. Branch - color & $\begin{array}{l}\text { Light-green (1), dark-green (2), purplish-green } \\
\text { (3), purple (4) }\end{array}$ & $\begin{array}{l}1(21 \%) \\
2(79 \%)\end{array}$ & $\begin{array}{l}1(42 \%) \\
2(58 \%)\end{array}$ & $\begin{array}{l}1(83 \%) \\
2(17 \%)\end{array}$ & $3(100 \%)$ & $\begin{array}{l}1(67 \%) \\
3(33 \%)\end{array}$ & $\begin{array}{l}1(50 \%) \\
2(12 \%) \\
3(37 \%)\end{array}$ \\
\hline 2. Leaf blade - shape & $\begin{array}{l}\text { Lanceolate (1), ovate (2), cordate (3), oblong ( } 4) \text {, } \\
\text { elliptic (5), split (6), cracked ( } 7) \text {, sectioned ( } 8)\end{array}$ & $2(100 \%)$ & $\begin{array}{l}2(92 \%) \\
4(8 \%)\end{array}$ & $2(100 \%)$ & $6(100 \%)$ & $6(100 \%)$ & $6(100 \%)$ \\
\hline 3. Leaf blade - division & $\begin{array}{l}\text { Simple (1), bilobed (2), trilobed (3), pentalobed } \\
\text { (4), heptalobed (5) }\end{array}$ & $1(100 \%)$ & $1(100 \%)$ & $1(100 \%)$ & $3(100 \%)$ & $3(100 \%)$ & $3(100 \%)$ \\
\hline 4. Leaf blade - length & $\begin{array}{l}\text { Short, }<8 \mathrm{~cm} \text { (3); average, } 8-15 \mathrm{~cm}(5) \text {; long, }>15 \\
\mathrm{~cm}(7)\end{array}$ & $5(100 \%)$ & $\begin{array}{l}3(4 \%) \\
5(96 \%)\end{array}$ & $5(100 \%)$ & $\begin{array}{l}3(46 \%) \\
5(54 \%)\end{array}$ & $\begin{array}{l}3(4 \%) \\
5(96 \%)\end{array}$ & $5(100 \%)$ \\
\hline 5. Leaf blade - maximum width & $\begin{array}{l}\text { Narrow, }<8 \mathrm{~cm}(3) \text {; average, } 8-15 \mathrm{~cm}(5) \text {; wide, } \\
>15 \mathrm{~cm}(7)\end{array}$ & $3(100 \%)$ & $3(100 \%)$ & $3(100 \%)$ & $\begin{array}{l}3(12 \%) \\
5(88 \%)\end{array}$ & $5(100 \%)$ & $5(100 \%)$ \\
\hline 6. Leaf blade - sinus & Absent (1), present (2) & $1(100 \%)$ & $1(100 \%)$ & $1(100 \%)$ & $2(100 \%)$ & $2(100 \%)$ & $2(100 \%)$ \\
\hline 7. Leaf blade - sinus depth & Shallow (3), average (5), deep (7) & - & - & - & $5(100 \%)$ & $5(100 \%)$ & $5(100 \%)$ \\
\hline 8. Leaf blade - wrinkling & Absent (1), present (2) & $1(100 \%)$ & $1(100 \%)$ & $1(100 \%)$ & $2(100 \%)$ & $1(100 \%)$ & $1(100 \%)$ \\
\hline 9. Leaf blade - hairiness & Absent (1), present (2) & $2(100 \%)$ & $2(100 \%)$ & $2(100 \%)$ & $1(100 \%)$ & $2(100 \%)$ & $2(100 \%)$ \\
\hline 10. Petiole - length & $\begin{array}{l}\text { Short, }<2 \mathrm{~cm}(3) \text {; average, } 2-4 \mathrm{~cm}(5) \text {; long, }> \\
4 \mathrm{~cm}(7)\end{array}$ & $\begin{array}{l}3(4 \%) \\
5(67 \%) \\
7(29 \%)\end{array}$ & $\begin{array}{l}3(71 \%) \\
5(29 \%)\end{array}$ & $\begin{array}{l}5(63 \%) \\
7(37 \%)\end{array}$ & $\begin{array}{l}3(54 \%) \\
5(46 \%)\end{array}$ & $\begin{array}{l}3(46 \%) \\
5(54 \%)\end{array}$ & $\begin{array}{c}5(8 \%) \\
7(92 \%)\end{array}$ \\
\hline $\begin{array}{l}\text { 11. Petiole - position of glands } \\
\text { (nectary) }\end{array}$ & $\begin{array}{l}\text { Adjacent to the leaf blade (1); next to the middle } \\
\text { of the petiole ( } 2 \text { ); adjacent to the leaf insertion in } \\
\text { the branch (3); distributed along the petiole (4) }\end{array}$ & $\begin{array}{l}3(92 \%) \\
4(8 \%)\end{array}$ & $\begin{array}{l}3(54 \%) \\
4(46 \%)\end{array}$ & $\begin{array}{l}3(71 \%) \\
4(29 \%)\end{array}$ & $1(100 \%)$ & $2(100 \%)$ & $4(100 \%)$ \\
\hline 12. Flower - hypanthium shape & Flat (1), campanulate (2), cylindrical (3) & $2(100 \%)$ & $2(100 \%)$ & $2(100 \%)$ & $2(100 \%)$ & $1(100 \%)$ & $3(100 \%)$ \\
\hline $\begin{array}{l}\text { 13. Flower - predominant color of } \\
\text { perianth (sepals and petals, internally) }\end{array}$ & $\begin{array}{l}\text { White (1), pinkish (2), red (3), purplish-red (4), } \\
\text { purple (5), purplish-blue (6), blue (7) }\end{array}$ & $3(100 \%)$ & $3(100 \%)$ & $3(100 \%)$ & $1(100 \%)$ & $2(100 \%)$ & $1(100 \%)$ \\
\hline $\begin{array}{l}\text { 14. Flower - predominant period of } \\
\text { anthesis }\end{array}$ & Morning (1), afternoon (2), night (3) & $1(100 \%)$ & $1(100 \%)$ & $1(100 \%)$ & $2(100 \%)$ & $1(100 \%)$ & $3(100 \%)$ \\
\hline 15. Flower - bract length & $\begin{array}{l}\text { Short, }<2 \mathrm{~cm}(3) \text {; average, } 2-4 \mathrm{~cm}(5) \text {; long, }>4 \\
\mathrm{~cm}(7)\end{array}$ & $\begin{array}{c}5(4 \%) \\
7(96 \%)\end{array}$ & $7(100 \%)$ & $\begin{array}{l}5(79 \%) \\
7(21 \%)\end{array}$ & $\begin{array}{l}3(88 \%) \\
7(12 \%)\end{array}$ & $\begin{array}{l}3(12 \%) \\
5(88 \%)\end{array}$ & $5(100 \%)$ \\
\hline 16. Flower - sepal length & $\begin{array}{l}\text { Short, }<3 \mathrm{~cm} \mathrm{(3);} \mathrm{average} 3-6 \mathrm{~cm}(5) \text {; long }>6 \\
\mathrm{~cm}(7)\end{array}$ & $5(100 \%)$ & $5(100 \%)$ & $\begin{array}{l}5(29 \%) \\
7(71 \%)\end{array}$ & $5(100 \%)$ & $5(100 \%)$ & $\begin{array}{c}3(4 \%) \\
5(96 \%)\end{array}$ \\
\hline 17. Flower - sepal width & $\begin{array}{l}\text { Narrow, }<1 \mathrm{~cm}(3) \text {; average, } 1-2 \mathrm{~cm}(5) ; \text { wide, }> \\
2 \mathrm{~cm}(7)\end{array}$ & $5(100 \%)$ & $5(100 \%)$ & $\begin{array}{l}3(4 \%) \\
5(96 \%)\end{array}$ & $5(100 \%)$ & $5(100 \%)$ & $3(100 \%)$ \\
\hline 18. Flower - petal length & $\begin{array}{l}\text { Short, }<3 \mathrm{~cm}(3) \text {; average } 3-6 \mathrm{~cm}(5) \text {; long, }>6 \\
\mathrm{~cm}(7)\end{array}$ & $5(100 \%)$ & $5(100 \%)$ & $\begin{array}{l}5(88 \%) \\
7(12 \%)\end{array}$ & $5(100 \%)$ & $5(100 \%)$ & $\begin{array}{l}3(4 \%) \\
5(96 \%)\end{array}$ \\
\hline 19. Flower - corona diameter & $\begin{array}{l}\text { Small, }<5 \mathrm{~cm}(3) \text {; average, } 5-10 \mathrm{~cm}(5) \text {; large, } \\
>10 \mathrm{~cm}(7)\end{array}$ & $\begin{array}{l}3(4 \%) \\
5(96 \%)\end{array}$ & $3(100 \%)$ & $3(100 \%)$ & $5(100 \%)$ & $5(100 \%)$ & $3(100 \%)$ \\
\hline 20. Flower - predominant corona color & $\begin{array}{l}\text { White (1), pinkish (2), red (3), purplish-red (4), } \\
\text { purple (5), purplish-blue (6), blue (7) }\end{array}$ & $1(100 \%)$ & $1(100 \%)$ & $1(100 \%)$ & $6(100 \%)$ & $2(100 \%)$ & $1(100 \%)$ \\
\hline $\begin{array}{l}\text { 21. Flower - banding (rings in } \\
\text { different colors, including white) in } \\
\text { the corona longest filaments }\end{array}$ & Absent (1), present (2) & $1(100 \%)$ & $1(100 \%)$ & $1(100 \%)$ & $2(100 \%)$ & $2(100 \%)$ & $1(100 \%)$ \\
\hline $\begin{array}{l}\text { 22. Flower - number of colored rings } \\
\text { (except for white ones) in the longest } \\
\text { corona filaments }\end{array}$ & One (1), more than one (2) & - & - & - & $2(100 \%)$ & $2(100 \%)$ & - \\
\hline 23. Flower - corona longest filaments & Smooth (1), wavy (2) & $1(100 \%)$ & $1(100 \%)$ & $1(100 \%)$ & $2(100 \%)$ & $1(100 \%)$ & $1(100 \%)$ \\
\hline 24. Fruit - shape & $\begin{array}{l}\text { Ovate (1), oblong (2), round (3), oblate (4), } \\
\text { ellipsoid (5), fusiform (6), obovate (7) }\end{array}$ & - & - & - & - & $1(100 \%)$ & $\begin{array}{l}1(96 \%) \\
3(4 \%)\end{array}$ \\
\hline 25. Fruit - longitudinal diameter & $\begin{array}{l}\text { Small, }<5 \mathrm{~cm}(3) \text {; average, } 5-15 \mathrm{~cm}(5) ; \text { large, }> \\
15 \mathrm{~cm}(7)\end{array}$ & - & - & - & - & $3(100 \%)$ & $\begin{array}{l}3(4 \%) \\
5(96 \%)\end{array}$ \\
\hline 26. Fruit - transverse diameter & $\begin{array}{l}\text { Small, }<5 \mathrm{~cm}(3) \text {; average, } 5-10 \mathrm{~cm}(5) ; \text { large, }> \\
10 \mathrm{~cm}(7)\end{array}$ & - & - & - & - & $3(100 \%)$ & $\begin{array}{l}3(67 \%) \\
5(33 \%)\end{array}$ \\
\hline $\begin{array}{l}\text { 27. Fruit - skin predominant color } \\
\text { (epidermis) }\end{array}$ & $\begin{array}{l}\text { Green (1), yellow (2), orange (3), pinkish (4), red } \\
(5) \text {, purple (6) }\end{array}$ & - & - & - & - & $1(100 \%)$ & $1(100 \%)$ \\
\hline
\end{tabular}


Table 1. Continuation...

\begin{tabular}{|c|c|c|c|c|c|c|c|}
\hline Descriptor & Identification of the characteristics & $\begin{array}{l}\text { BRS Estrela } \\
\text { do Cerrado }\end{array}$ & $\begin{array}{c}\text { BRS } \\
\text { Rubiflora }\end{array}$ & $\begin{array}{c}\text { BRS } \\
\text { Roseflora }\end{array}$ & $\begin{array}{l}\text { BRS Céu do } \\
\text { Cerrado }\end{array}$ & $\begin{array}{l}\text { BRS Rosea } \\
\text { Púrpura }\end{array}$ & $\begin{array}{l}\text { BRS Pérola } \\
\text { do Cerrado }\end{array}$ \\
\hline $\begin{array}{l}\text { 28. Fruit - lenticels distributed in } \\
\text { striated pattern }\end{array}$ & Absent (1), present (2) & - & - & - & - & $1(100 \%)$ & $1(100 \%)$ \\
\hline 29. Fruit - skin thickness & $\begin{array}{l}\text { Very thin, }<0.3 \mathrm{~cm}(1) \text {; thin, } 0.3-0.6 \mathrm{~cm}(2) \text {; } \\
\text { average, }>0.6-1 \mathrm{~cm}(3) \text {; thick, }>1-1.5 \mathrm{~cm}(4) \text {; } \\
\text { very thick, }>1.5 \mathrm{~cm}(5)\end{array}$ & - & - & - & - & $\begin{array}{l}2(88 \%) \\
3(12 \%)\end{array}$ & $\begin{array}{l}2(96 \%) \\
3(4 \%)\end{array}$ \\
\hline 30. Fruit - seed size & $\begin{array}{l}\text { Small, }<0.3 \mathrm{~cm}(3) \text {; average, } 0,3-0,7 \mathrm{~cm}(5) ; \\
\text { large, }<0,7 \mathrm{~cm}(7)\end{array}$ & - & - & - & - & - & $5(100 \%)$ \\
\hline 31. Fruit - pulp color & $\begin{array}{l}\text { Whitish (1), greenish-yellow (2), yellow ( } 3 \text { ), } \\
\text { orangish-yellow (4), orangish (5), dark-orangish } \\
\text { (6), red (7) }\end{array}$ & - & - & - & - & - & $\begin{array}{l}2(21 \%) \\
3(12 \%) \\
4(29 \%) \\
5(38 \%)\end{array}$ \\
\hline 32. Fruit - total soluble solids content & $\begin{array}{l}\text { Very low, }<7^{\circ} \text { Brix (1); low, } 7-10^{\circ} \text { Brix }(2) \text {; } \\
\text { average, }>10-13^{\circ} \text { Brix (3); high, }>13-17^{\circ} \text { Brix } \\
\text { (4); very high, }>17^{\circ} \text { Brix (5) }\end{array}$ & - & - & - & - & - & $\begin{array}{l}3(46 \%) \\
4(54 \%)\end{array}$ \\
\hline $\begin{array}{l}\text { 33. Fruit - seed numbers, with natural } \\
\text { pollination, by ripe fruit }\end{array}$ & $\begin{array}{l}\text { Very small, }<50(1) ; \text { small, } 50-100(3) \text {; average, } \\
>100-200(5) ; \text { large, }>200-400 \text { (7); very large, } \\
>400(9)\end{array}$ & - & - & - & - & - & $\begin{array}{l}3(8 \%) \\
5(71 \%) \\
7(21 \%)\end{array}$ \\
\hline
\end{tabular}

- Does not show the characteristic.

and pseudo-qualitative descriptors include: branch color; leaf blade (shape, division, sinus, sinus depth, wrinkling, leaf hairiness, and nectary position in the petiole); flower (hypanthium shape, prevailing perianth color, prevailing onset of anthesis, prevailing corona color, banding in the corona longest filaments, number of colored rings in the longest corona filaments); and fruit (shape, skin color, lenticels distributed in an striated pattern, and pulp color).

The quantitative characteristics are: leaf blade length (LBL); leaf blade maximum width (LBMW); petiole length (PL); bract length (BL); sepal length (SL); sepal width (SW); petal length (PL); corona diameter (CD); longitudinal diameter of fruit (LDF); transverse diameter of fruit (TDF); fruit skin thickness (FST); seed size (SS); total soluble solids content (TSSC); and number of seed per fruit (NSPF).

Qualitative and pseudo-qualitative characteristics were analyzed according to the phenotypic class of Passiflora spp. descriptors to which numeric sequential codes were assigned (Brasil, 2016). To define the phenotypic class of a descriptor in each cultivar, analyses were carried out in twenty-four branches, leaves, flowers or fruit by at least 12 plants. These 24 structures were measured for their quantitative characteristics with the aid of a digital caliper, a digital refractometer, and a precision scale, according to the descriptor being evaluated at the time. Fruit were transversally cut in halves, and three different measurements were performed in different fruit positions, using their averages to define the phenotypic class to evaluate the skin thickness. Each code of phenotypic class assigned to each of the 24 structures was evaluated by the analysis of its frequency distribution. The most frequent code was chosen to characterize each descriptor of the evaluated cultivars.

Genetic dissimilarities among the cultivars were estimated based on the defined codes for 33 descriptors and six cultivars by using the indices of simple coincidence of the categorical characteristics, with the aid of the Genes software (Cruz, 2013). Cluster analysis was performed from the genetic dissimilarity matrix obtained using as a criterion the UPGMA (unweighted pair-group method arithmetic average) and a graphic dispersion based on a multidimensional scale, using the principal coordinate method with the aid of the SAS software (SAS Institute Inc., Cary, NC, USA).

The fourteen quantitative descriptors were also analyzed separately. Eight descriptors related to leaf and flower were evaluated in all cultivars. However, six descriptors related to fruit were only studied in 'BRS Pérola do Cerrado' that produces fruit in natural conditions, and in 'BRS Rosea Púrpura' that produces parthenocarpic fruit (pulpless and seedless). For the quantitative analyses, a completely randomized 
block experimental design was used, with six treatments ('BRS Rubiflora', 'BRS Rosea Púrpura', 'BRS Roseflora', 'BRS Céu do Cerrado', 'BRS Estrela do Cerrado', and 'BRS Pérola do Cerrado'), and four replicates, each one representing the mean of six structures measurements/classifications (branches, leaves, flowers, and fruit). After performing the analysis of variance, the means were compared by the Tukey's test, at $1 \%$ probability. Genetic dissimilarities were measured among the cultivars based on eight quantitative descriptors that were common to the six cultivars, using the Mahalanobis distance with the aid of the Genes Program (Cruz, 2013). Cluster and graphic dispersion analyses were also performed from the genetic dissimilarity matrix, as reported for the categorical characteristics. The relative contribution of quantitative descriptors to the genetic divergence among the cultivars was estimated according to the criterion proposed by Singh (1981).

The molecular characterization of six ornamental passion fruit cultivars, using RAPD and ISSR markers, was performed at the Laboratório de Genética e Biologia Molecular of Embrapa Cerrados, in Planaltina, DF, Brazil.

Genomic DNA was extracted from leaf tissue in the intermediary stage of maturation of each material, using the CTAB (cetyl trimethylammonium bromide) method with modifications (Faleiro et al., 2003).

Ten decamer primers were used to obtain RAPD markers. The amplification reactions were carried out using a total volume of $13 \mu \mathrm{L}$, containing $10 \mathrm{mmol} \mathrm{L}^{-1}$ Tris- $\mathrm{HCl}(\mathrm{pH} 8.3), 50 \mathrm{mmol} \mathrm{L}^{-1} \mathrm{KCl}, 3 \mathrm{mmol} \mathrm{L} \mathrm{L}^{-1}$ $\mathrm{MgCl}_{2}, 100 \mu \mathrm{mol} \mathrm{\textrm {L } ^ { - 1 }}$ of each deoxyribonucleotide (dATP, dTTP, dGTP, and dCTP), $0.4 \mu \mathrm{mol} \mathrm{L}^{-1}$ of a primer (Operon Technologies Inc., Alameda, CA, USA), one unit of Taq polymerase, and approximately 15 ng DNA. Amplifications were carried out in a thermocycler programmed for 40 cycles, each one constituted by the following sequence: $15 \mathrm{~s}$ at $94^{\circ} \mathrm{C}$, $30 \mathrm{~s}$ at $35^{\circ} \mathrm{C}$, and $90 \mathrm{~s}$ at $72^{\circ} \mathrm{C}$. After 40 cycles, there was an extension final phase for $6 \mathrm{~min}$ at $72^{\circ} \mathrm{C}$, and the temperature was reduced to $4^{\circ} \mathrm{C}$.

For ISSR markers, DNA was amplified using seven primers and the following reaction: $20 \mathrm{ng}$ of genomic DNA, 1 unit Taq DNA polymerase, $0.3 \mu \mathrm{mol} \mathrm{L}^{-1}$ of primer in $13 \mu \mathrm{L}$ solution containing $10 \mathrm{mmol} \mathrm{L}^{-1}$ Tris- $\mathrm{HCl}\left(\mathrm{pH} 8.3\right.$ ), $50 \mathrm{mmol} \mathrm{L}^{-1} \mathrm{KCl}, 3 \mathrm{mmol} \mathrm{L}^{-1}$ $\mathrm{MgCl}_{2}, 100 \mu \mathrm{mol} \mathrm{\textrm {L } ^ { - 1 }}$ of each deoxyribonucleotides
(dATP, dTTP, dGTP, and dCTP) in water until reaching $13 \mu \mathrm{L}$ volume. Amplifications were performed in a thermocycler programmed for $5 \mathrm{~min}$ at $94^{\circ} \mathrm{C}$, with 35 cycles each in the following sequence: $40 \mathrm{~s}$ at $94^{\circ} \mathrm{C}$, $40 \mathrm{~s}$ at $48^{\circ} \mathrm{C}$, and $1 \mathrm{~min}$ at $72^{\circ} \mathrm{C}$. After 35 cycles, there was an extension final phase for two min at $72^{\circ} \mathrm{C}$, and the temperature was reduced to $4^{\circ} \mathrm{C}$.

After RAPD and ISSR amplifications, $3 \mu \mathrm{L}$ of a mixture of bromophenol blue $(0.25 \%)$ and glycerol $(60 \%)$ in water were added to each sample. The samples were poured over the agarose gel $(1.2 \%)$ which was then stained using ethidium bromide and embedded in a TBE $\left(90 \mathrm{mmol} \mathrm{L}^{-1}\right.$ Tris-Borate, $1 \mathrm{mmol} \mathrm{L}^{-1}$ EDTA) buffer. The electrophoretic separation lasted approximately four hours at 90 volts. After the run, gels were photographed under ultraviolet light.

The obtained RAPD and ISSR markers were converted into a binary data matrix, which were used to estimate the genetic distance between cultivars based on the Nei and Li similarity coefficients, with the aid of Genes software (Cruz, 2013). Genetic distance matrices were used for the cluster analyses by a dendogram, using the UPGMA as a cluster criterion, and graphic dispersion based on multidimensional scales with the principal coordinate method, aided by the SAS (SAS Institute Inc., Cary, NC, USA) and Statistica softwares (Statistica, Tulsa, OK, USA).

Finally, the correlation of genetic distances among the cultivars was also estimated based on the 33 categorical morphoagronomic descriptors, and on eight quantitative descriptors and molecular markers, based on the Pearson's correlation coefficient with the aid of the Genes software (Cruz, 2013).

\section{Results and Discussion}

Different numbers of descriptors were obtained for the six ornamental passion fruit cultivars (Table 1), including 32 descriptors for BRS Pérola do Cerrado, 29 descriptors for BRS Rosea Púrpura, 23 descriptors for BRS Céu do Cerrado, and 21 descriptors for BRS Rubiflora, BRS Roseflora, and BRS Estrela do Cerrado. 'BRS Pérola do Cerrado' does not show colored rings in the longest corona filaments, 'BRS Rosea Púrpura' shows parthenocarpic fruit, that is, there is no fertilization and no seed formation, therefore, it was not possible to evaluate the four traits related to pulp and fruit seed. 'BRS Céu do Cerrado' 
does not produce fruit, therefore, it was not possible to estimate the ten characteristics related to fruit. 'BRS Rubiflora', 'BRS Roseflora', and 'BRS Estrela do Cerrado' do not produce fruit in natural conditions, showing neither leaf blade sinus nor colored rings in the longest filaments of the corona.

When considering the morphological and agronomic descriptors, and based on the highest frequency to define a class, only the traits leaf blade length and petal length were not effective for the differentiation between the six cultivars showing the same phenotypical category. However, 'BRS Rubiflora', 'BRS Roseflora', and 'BRS Estrela do Cerrado' showed the most similar characteristics (Table 1). The cluster analysis and the graphic dispersion generated by the multivariate analysis, based on simple coincidence of 33 categorical descriptors (Figures $1 \mathrm{~A}$ and $2 \mathrm{~A}$ ) evidenced a cluster tendency in these three cultivars, that show simple leaves and red flowers as their main characteristics. These cultivars show in their genealogy the same genetic basis $(P$. coccinea and $P$. setacea), which explains the fact that only five of 21 descriptors showed a different code, allowing of their differentiation (branch color; petiole, bract, and sepal length; and corona diameter). Among those cultivars, the most morphoagronomic similar ones were 'BRS Estrela do Cerrado' and 'BRS Rubiflora', which differed only for their petiole length and corona diameter.

Based on the highest phenotypical frequency, 'BRS Rosea Púrpura' shows a predominant light-green color of branch, hairy leaves, average petiole length, nectary located in the middle of the petiole, flat hypanthium, pinkish sepals and petals, morning anthesis, average bract length, average sepal width, and an average diameter of pinkish corona that shows more than one colored ring in the longest smooth filaments (Table 1).

'BRS Céu do Cerrado', however, shows purplishgreen branches, wrinkled leaves, short petiole, and nectary adjacent to the leaf blade, campanulate hypanthium, white perianth, afternoon anthesis, short bract length, sepal with an average length and $1-2 \mathrm{~cm}$ width, average petal length, purplish-blue corona with an average diameter and with more than one colored ring in the longest and wavy filaments.

'BRS Pérola do Cerrado' has predominantly lightgreen branches, hairy leaves, long petioles with nectary distributed along its length, cylindric hypanthium, white petals and sepals, nocturnal anthesis, average bract length, narrow sepal, white corona with a short diameter and long smooth filaments.

'BRS Rosea Púrpura' and 'BRS Pérola do Cerrado' showed oval green fruit, with a short transverse diameter and thin skin. The longitudinal diameter of fruit was classified as average for 'BRS Pérola do Cerrado', and as small for 'BRS Rosea Púrpura'. Some descriptors were evaluated only for 'BRS Pérola do Cerrado', which showed an average seed size from 0.3 to $0.7 \mathrm{~cm}$, orange pulp, high content of total soluble solids from $13-17^{\circ} \mathrm{Brix}$, and average number of seed from 100-200.
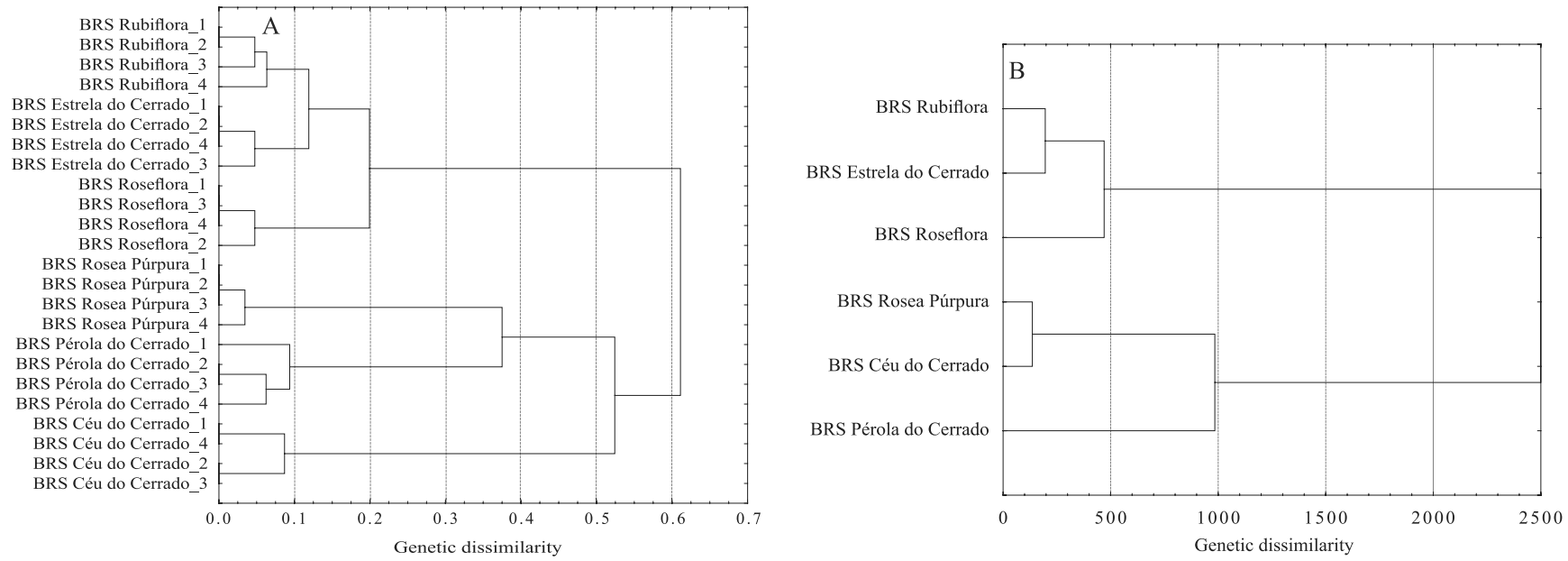

Figure 1. Cluster analysis of six ornamental passion fruit (Passiflora spp.) cultivars, based on a genetic distance matrix calculated through 33 categorical descriptors (A), and eight quantitative descriptors (B), in four replicates. UPGMA was used as the cluster criterion. 
The analysis of variance using the F-test (Table 2) showed highly-significant differences for eight quantitative descriptors of leaves and flowers of the six cultivars (LBL, LBMW, PL, BL, SL, SW, $\mathrm{PL}$, and $\mathrm{CD}$ ), suggesting genetic variability in the evaluated passion fruit. As to fruit descriptors analyzed between the two cultivars, only skin thickness was statistically similar. The coefficients of variation were low, and the coefficient of determination was high for all quantitative descriptors, showing the accuracy and reliability of the data (Cruz et al., 2004).

The mean comparisons showed that 'BRS Rubiflora' has the longest bract $(4.86 \mathrm{~cm})$ and widest sepal $(1.52$ $\mathrm{cm})$; 'BRS Rosea Púrpura' shows the highest thickness of fruit skin $(0.55 \mathrm{~cm})$; and 'BRS Roseflora' shows the longest leaf blade $(12 \mathrm{~cm})$, sepal $(6.13 \mathrm{~cm})$, and petal $(5.82 \mathrm{~cm})$; 'BRS Céu do Cerrado' shows the largest corona diameter $(7.97 \mathrm{~cm})$; and 'BRS Pérola do Cerrado' shows the widest leaf blade $(10.78 \mathrm{~cm})$, the longest petiole $(4.83 \mathrm{~cm})$, and the largest longitudinal $(5.98 \mathrm{~cm})$ and transverse diameter of fruit $(4.89 \mathrm{~cm})$ (Table 3). Significant differences among Passiflora species with ornamental potential were also observed by Santos et al. (2011a), when analyzing 14 quantitative descriptors that indicated a genetic variability among these materials.

The relative contribution of eight quantitative descriptors for the genetic distance involving the six cultivars varied from 3.48 to $33.92 \%$ (Table 4 ). The descriptor that contributed most to the differentiation was the leaf blade maximum width (approximately $34 \%$ ), followed by petal length (26.17\%). The descriptors that contributed least to the differentiation were sepal length (3.48\%) and corona diameter (3.81\%). Santos et al. (2011a) quantified the genetic diversity of passion fruit species with ornamental potential, and observed a higher-relative contribution for flower diameter (26.27\%) and peduncle length (26.34\%). However, these descriptors are not part of the list evaluated in the present study.

The cluster analysis and graphic dispersion carried out using the quantitative descriptors (Figures $1 \mathrm{~B}$ and 2 B) evidenced the coherence of these data when the same analyses were performed with the categorical

Table 2. Treatment significance in percentage by the F-test and genetic parameters of data related to the quantitative characteristics of six ornamental passion (Passiflora spp.) fruit cultivars.

\begin{tabular}{|c|c|c|c|c|c|c|c|c|c|c|c|}
\hline Variation source & $\begin{array}{l}\text { LBL } \\
(\mathrm{cm})\end{array}$ & $\begin{array}{l}\text { LBMW } \\
(\mathrm{cm})\end{array}$ & $\begin{array}{l}\text { PL } \\
(\mathrm{cm})\end{array}$ & $\begin{array}{l}\mathrm{BL} \\
(\mathrm{cm})\end{array}$ & $\begin{array}{l}\mathrm{SL} \\
(\mathrm{cm})\end{array}$ & $\begin{array}{l}\text { SW } \\
(\mathrm{cm})\end{array}$ & $\begin{array}{l}\mathrm{PL} \\
(\mathrm{cm})\end{array}$ & $\begin{array}{l}\mathrm{CD} \\
(\mathrm{cm})\end{array}$ & $\begin{array}{l}\text { LDF } \\
(\mathrm{cm})\end{array}$ & $\begin{array}{l}\text { TDF } \\
(\mathrm{cm})\end{array}$ & $\begin{array}{c}\mathrm{ST} \\
(\mathrm{cm})\end{array}$ \\
\hline Treatment (significance) & $0.00 * *$ & $0.00 * *$ & $0.00 * *$ & $0.00 * *$ & $0.00 * *$ & $0.00 * *$ & $0.00 * *$ & $0.00 * *$ & $0.00 * *$ & $0.00 * *$ & $0.04 *$ \\
\hline Average & 10.19 & 8.08 & 2.95 & 3.27 & 4.64 & 1.26 & 4.58 & 5.15 & 5.14 & 4.17 & 0.53 \\
\hline Coefficient of variation (\%) & 5.77 & 4.05 & 9.03 & 4.89 & 3.36 & 3.57 & 1.95 & 6.07 & 3.13 & 3.62 & 5.55 \\
\hline Coefficent of determination & 96.05 & 99.54 & 98.77 & 99.62 & 99.50 & 99.02 & 99.81 & 99.39 & 99.54 & 99.45 & 85.95 \\
\hline
\end{tabular}

LBL, leaf blade length; LBMW, leaf blade maximum width; PL, petiole length; BL bract length; SL, sepal length; SW, sepal width; PL, petal length; CD, corona diameter; LDF, longitudinal diameter of fruit; TDF transverse diameter of fruit; and ST, skin thickness. **, *Significant at 1 and $5 \%$ probability, respectively, by the F-test.

Table 3. Means of quantitative characteristics of six ornamental passion (Passiflora spp.) fruit cultivars ${ }^{(1)}$.

\begin{tabular}{lccccccccccc}
\hline Cultivar & $\begin{array}{c}\text { LBL } \\
(\mathrm{cm})\end{array}$ & $\begin{array}{c}\text { LBMW } \\
(\mathrm{cm})\end{array}$ & $\begin{array}{c}\text { PL } \\
(\mathrm{cm})\end{array}$ & $\begin{array}{c}\mathrm{BL} \\
(\mathrm{cm})\end{array}$ & $\begin{array}{c}\text { SL } \\
(\mathrm{cm})\end{array}$ & $\begin{array}{c}\text { SW } \\
(\mathrm{cm})\end{array}$ & $\begin{array}{c}\text { PL } \\
(\mathrm{cm})\end{array}$ & $\begin{array}{c}\text { CD } \\
(\mathrm{cm})\end{array}$ & $\begin{array}{c}\text { LDF } \\
(\mathrm{cm})\end{array}$ & $\begin{array}{c}\text { TDF } \\
(\mathrm{cm})\end{array}$ & $\begin{array}{c}\text { ST } \\
(\mathrm{cm})\end{array}$ \\
\hline BRS Rubiflora & $9.73 \mathrm{~cd}$ & $5.40 \mathrm{~d}$ & $1.93 \mathrm{c}$ & $4.86 \mathrm{a}$ & $5.32 \mathrm{~b}$ & $1.52 \mathrm{a}$ & $5.35 \mathrm{~b}$ & $4.07 \mathrm{c}$ & - & - & - \\
BRS Rosea Púrpura & $9.23 \mathrm{~cd}$ & $10.18 \mathrm{ab}$ & $2.04 \mathrm{c}$ & $2.42 \mathrm{c}$ & $4.09 \mathrm{c}$ & $1.39 \mathrm{~b}$ & $4.08 \mathrm{c}$ & $6.53 \mathrm{~b}$ & $4.30 \mathrm{~b}$ & $3.45 \mathrm{~b}$ & $0.55 \mathrm{a}$ \\
BRS Roseflora & $12.00 \mathrm{a}$ & $6.41 \mathrm{c}$ & $3.66 \mathrm{~b}$ & $3.87 \mathrm{~b}$ & $6.13 \mathrm{a}$ & $1.13 \mathrm{c}$ & $5.82 \mathrm{a}$ & $2.89 \mathrm{~d}$ & - & - & - \\
BRS Céu do Cerrado & $8.13 \mathrm{~d}$ & $9.79 \mathrm{~b}$ & $1.90 \mathrm{c}$ & $1.61 \mathrm{~d}$ & $3.52 \mathrm{~d}$ & $1.36 \mathrm{~b}$ & $3.65 \mathrm{~d}$ & $7.97 \mathrm{a}$ & - & - & - \\
BRS Estrela do Cerrado & $11.70 \mathrm{ab}$ & $5.94 \mathrm{~cd}$ & $3.33 \mathrm{~b}$ & $4.46 \mathrm{a}$ & $5.36 \mathrm{~b}$ & $1.30 \mathrm{~b}$ & $5.28 \mathrm{~b}$ & $6.04 \mathrm{~b}$ & - & - & - \\
BRS Pérola do Cerrado & $10.35 \mathrm{bc}$ & $10.78 \mathrm{a}$ & $4.83 \mathrm{a}$ & $2.41 \mathrm{c}$ & $3.46 \mathrm{~d}$ & $0.88 \mathrm{~d}$ & $3.32 \mathrm{e}$ & $3.42 \mathrm{~cd}$ & $5.98 \mathrm{a}$ & $4.89 \mathrm{a}$ & $0.50 \mathrm{a}$ \\
\hline
\end{tabular}

${ }^{(1)}$ Means followed by equal lowercase, in the columns, do not differ, by the Tukey's test, at 1\% probability. LBL, leaf blade length; LBMW, leaf blade maximum width; PL, petiole length; BL bract length; SL, sepal length; SW, sepal width; PL, petal length; CD, corona diameter; LDF, longitudinal diameter of fruit; TDF transverse diameter of fruit; and ST, skin thickness. - BRS Rubiflora, BRS Roseflora, BRS Céu do Cerrado, and BRS Estrela do Cerrado cultivars do not produce fruits. 
descriptors (Figures $1 \mathrm{~A}$ and $2 \mathrm{~A}$ ), and also proved the importance of using morphoagronomic descriptors to differentiate cultivars through genetic variability. The worth of using descriptors for the analysis of differentiation was also observed by Viana et al. (2010), Santos et al. (2011a, 2014) and Paiva et al. (2014) when studying the Passiflora genus.

The validation rate, that is, the percentage of coincidence between obtained descriptors and the cultivar descriptors, used in the protection requests, was high in different ornamental passion fruit cultivars (100\% for 'BRS Rosea Púrpura', 97\% for 'BRS Pérola do Cerrado', 96\% for 'BRS Céu do Cerrado', 90\% for 'BRS Estrela do Cerrado', 81\% for 'BRS Rubiflora', and $71 \%$ for 'BRS Roseflora'). These rates show how useful the current descriptors are in the protection requests. However, it also shows that some adjustments are necessary to improve the accuracy of phenotypical evaluations.

The phenotypical variability found for descriptors in the same cultivar, and even in the same plant, might have caused errors in the obtention of descriptors in the time of request for the cultivar protection. The number of structures to be evaluated, and the right method to estimate quantitative characteristics could have also increased the descriptors validation rate.

A higher-validation rate could have been obtained if an illustrated manual for descriptors was available. Characteristics such as prevailing color of perianth, pulp color, and corona diameter would be easier analyzed using reference standards.

The inclusion of the same terms would standardize and facilitate evaluations in different studies by different evaluators, as follows: "predominant", in

Table 4. Relative contribution of eight quantitative descriptors analyzed for their divergence in descending order of importance.

\begin{tabular}{lc}
\hline Descriptor & Value (\%) \\
\hline Leaf blade maximum width (LBMW) & 33.92 \\
Petal length (PL) & 26.17 \\
Sepal width (SW) & 10.28 \\
Bract length (BL) & 8.84 \\
Petiole length (PL) & 8.75 \\
Leaf blade length (LBL) & 4.75 \\
Corona diameter (CD) & 3.81 \\
Sepal length (SL) & 3.48 \\
\hline
\end{tabular}

qualitative descriptors that showed phenotypical variations (color of the branch, leaf blade shape, and nectary position); "fimbria", in descriptors related to the corona; "length", in the longitudinal diameter descriptor; and "width", in the transverse diameter.

The inclusion of more classes in some quantitative descriptors (leaf blade length, leaf blade maximum width, corona diameter, longitudinal and transverse diameter of fruit), and qualitative descriptors (division of the leaf blade, prevailing color in the perianth, color of the fruit skin), and the inclusion of some descriptors (flower diameter, androgynophore length, and anthocyanine in the androgynophore, filament, and styles) could provide a better differentiation among the cultivars.

The exclusion of the descriptor "lenticels distributed in an striated pattern" would contribute a highervalidation rate, as this descriptor generates doubts during the evaluation which might cause errors. The combination of the characteristics "banding at the corona filaments" (presence and absence), and "number of colored rings" (one or more than one) is also indicated to avoid the lack of this second characteristic when filling out the form (Table 1, descriptor number 22).

The characterization of the six ornamental passion fruit matrices by molecular markers yielded 117 RAPD markers and 125 ISSR markers (Table 5), resulting in an average of 11.7 and 17.9 markers by primer, respectively. From the total number of markers, $82 \%$ were polymorphic in RAPD, and 91.2\% were polymorphic in ISSR, showing the highgenetic variability among the six cultivars. A high polymorphism indicating the high-genetic variability of the Passiflora genus by RAPD markers has already been reported by Bellon et al. (2009, 2014), Viana et al. (2010), Castro et al. (2011), and Cerqueira-Silva et al. (2012). This fact have been verified also by Santos et al. (2011b), Costa et al. (2012), and Sousa et al. (2015) by using ISSR markers.

The genetic distance among the six ornamental passion fruit cultivars ranged from 0.128 to 0.614 by RAPD markers and from 0.19 to 0.75 by ISSR markers (Table 6). The shortest genetic distance (0.128) was found between 'BRS Roseflora' and 'BRS Estrela do Cerrado' by RAPD and between 'BRS Rubiflora' and 'BRS Roseflora' (0.19) using ISSR. The largest distance was found between 'BRS Céu do Cerrado' and 'BRS Pérola do Cerrado' (0.614 and 0.75 for RAPD and 
ISSR, respectively) because they showed completely different genealogies. Additionaly, the shortest genetic distances implied a cluster tendency (Figures 3 and 4) among three cultivars of the same genetic basis in their genealogy, a fact that also occurred in the morphoagronomic characterization. However, a cluster tendency was observed for these cultivars with 'BRS Rosea Púrpura'.

In general, a coherence was found among the genetic distance, cluster analysis, and graphic dispersion for the six ornamental passion fruit cultivars, according to the categorical descriptors and to RAPD and ISSR. This outcome is explained by the high and significant correlation among the calculated distances based on these variables (Table 7). The highest correlation (0.92) was found between the genetic distances using the two molecular DNA markers.

No significant correlation was found for the calculated genetic dissimilarities using quantitative descriptors and molecular markers, which shows that morphoagronomic quantitative traits does not always accurately represent the real genetic distance, obtained by the molecular characterization in the DNA. When thinking about the characterization of genetic resources or cultivars, one can state that the analysis using qualitative and quantitative morphoagronomic
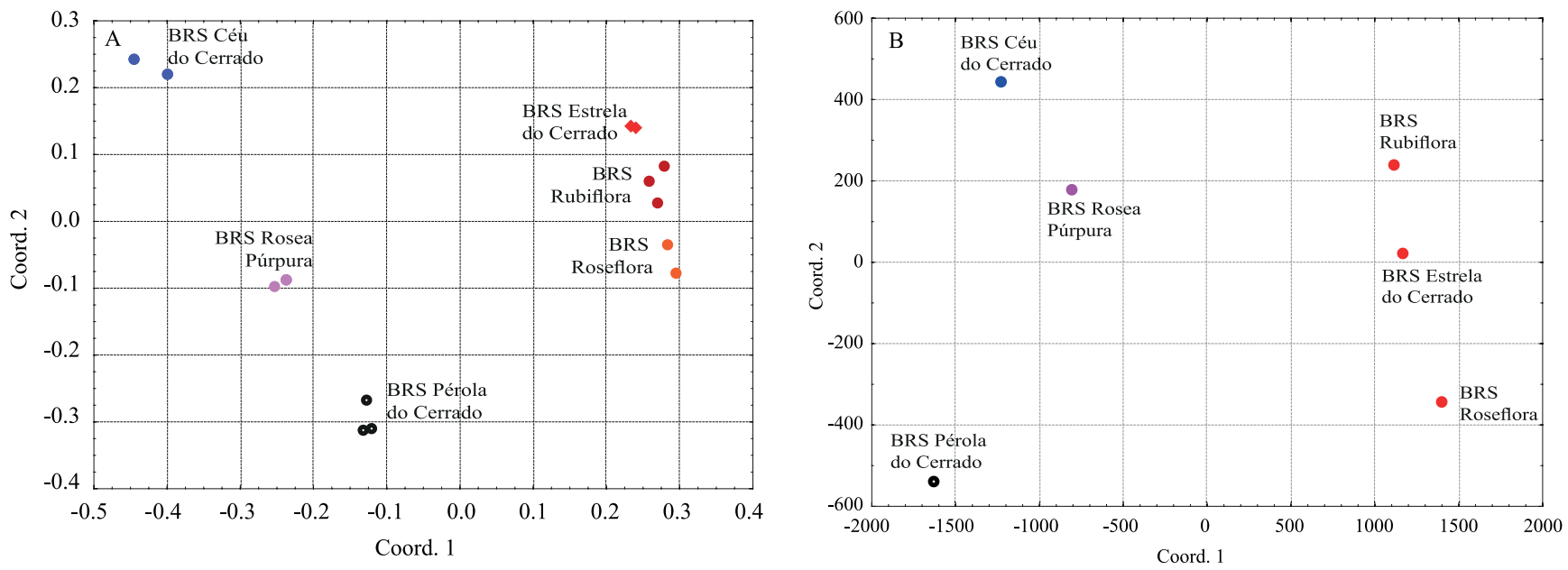

Figure 2. Graphic dispersion of six ornamental passion fruit (Passiflora spp.) cultivars, based on a genetic distance matrix calculated through 33 categorical descriptors (A), and eight quantitative descriptors (B), in four replicates.
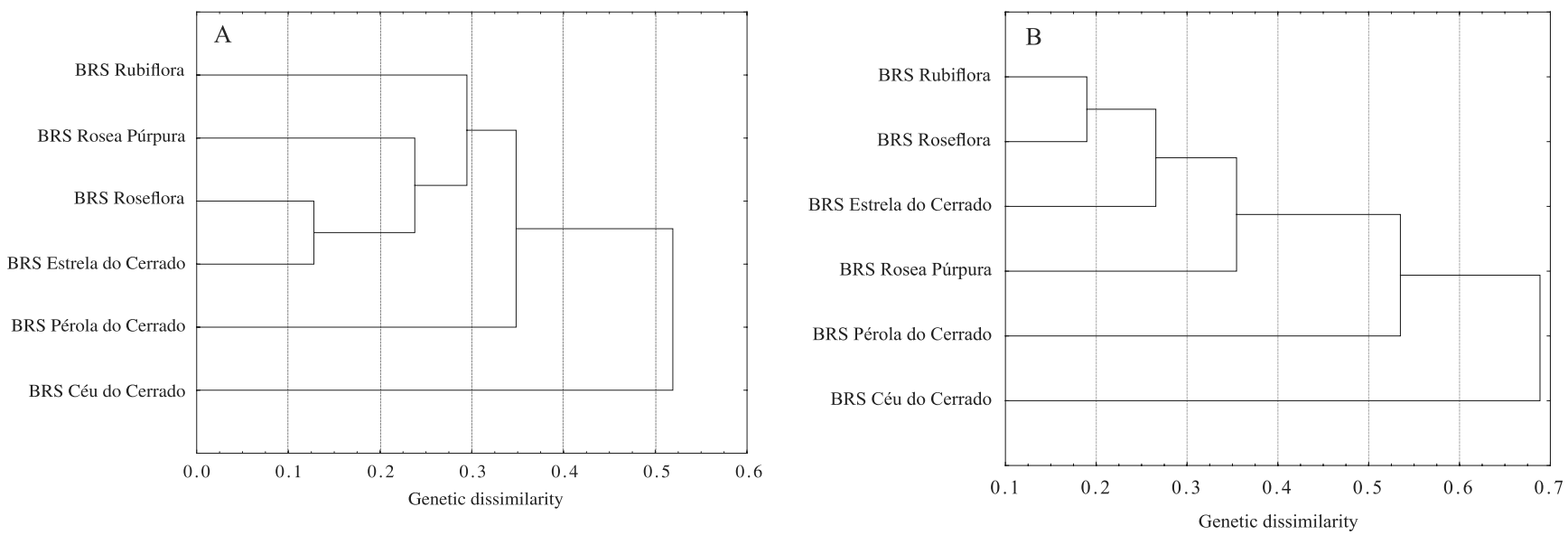

Figure 3. Cluster analysis of six ornamental passion fruit (Passiflora spp.) cultivars, based on a genetic distance matrix using 117 RAPD markers (A), and 125 ISSR markers (B). UPGMA was used as the cluster criterion. 

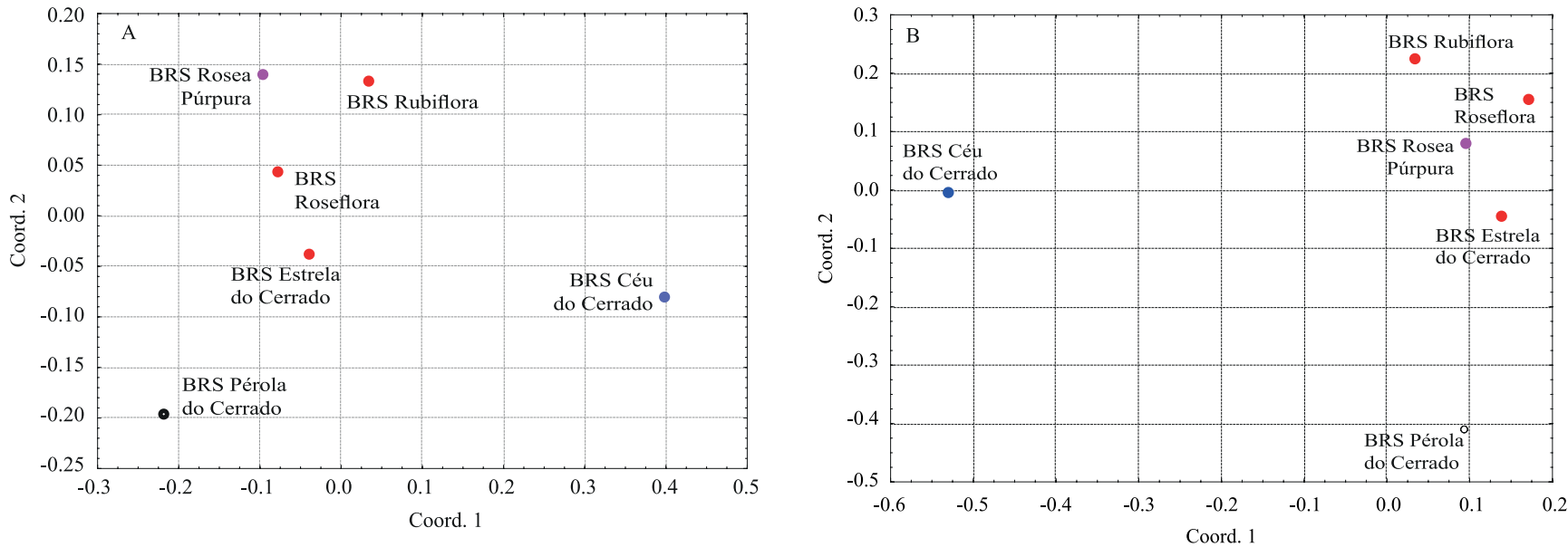

Figure 4. Graphic dispersion of six ornamental passion fruit (Passiflora spp.) cultivars, based on a genetic distance matrix calculated using 117 RAPD markers (A), and 125 ISSR markers (B).

Table 5. Primers used to obtain RAPD and ISSR markers for six ornamental passion fruit (Passiflora spp.) cultivars, and the respective numbers of polymorphic and monomorphic bands.

\begin{tabular}{lccc}
\hline Primer & 5' $\rightarrow$ ' ' Sequence & $\begin{array}{c}\text { Number of } \\
\text { polymorphic } \\
\text { bands }\end{array}$ & $\begin{array}{c}\text { Number of } \\
\text { monomorphic } \\
\text { bands }\end{array}$ \\
\hline RAPD OPD-07 & TTGGCACGGG & 6 & 0 \\
RAPD OPD-10 & GGTCTACACC & 12 & 1 \\
RAPD OPE-16 & GGTGACTGTG & 8 & 3 \\
RAPD OPE-18 & GGACTGCAGA & 14 & 4 \\
RAPD OPF-17 & AACCCGGGAA & 11 & 3 \\
RAPD OPG-01 & CTACGGAGGA & 4 & 3 \\
RAPD OPG-05 & CTGAGACGGA & 11 & 2 \\
RAPD OPG-08 & GGCTCATGTG & 11 & 2 \\
RAPD OPG-17 & ACGACCGACA & 9 & 1 \\
RAPD OPH-04 & GGAAGTGCCC & 10 & 2 \\
\hline Total & & 96 & 21 \\
\hline ISSR-5 & AGCAGCAGCAGCAGC & 15 & 1 \\
ISSR-6 & AGGAGGAGGAGGAGG & 20 & 0 \\
ISSR-7 & CAGCAGCAGCAGCAG & 15 & 3 \\
ISSR-8 & CGAGAGAGAGAGAGAGA & 15 & 1 \\
ISSR-13 & GAGAGAGAGAGAGAGAC & 10 & 2 \\
ISSR-14 & CYGAGAGAGAGAGAGAGA & 20 & 1 \\
ISSR-15 & CYGTGTGTGTGTGTGTGT & 19 & 3 \\
\hline Total & & 114 & 11 \\
\hline & & & \\
\hline
\end{tabular}

descriptors and also molecular markers show complementary functions.

The use of the list of minimum descriptors recommended by the SNPC, composed by
Table 6. Genetic dissimilarity matrix among six matrices of ornamental passion fruit cultivars, based on Nei and $\mathrm{Li}$ coefficient complement, using 117 RAPD markers (below the diagonal) and 125 ISSR markers (above the diagonal) ${ }^{(1)}$.

\begin{tabular}{lcccccc}
\hline Number & 1 & 2 & 3 & 4 & 5 & 6 \\
\hline 1 & 0 & 0.374 & 0.190 & 0.642 & 0.304 & 0.613 \\
2 & 0.353 & 0 & 0.328 & 0.685 & 0.362 & 0.558 \\
3 & 0.235 & 0.232 & 0 & 0.694 & 0.227 & 0.567 \\
4 & 0.475 & 0.541 & 0.492 & 0 & 0.673 & 0.750 \\
5 & 0.296 & 0.244 & 0.128 & 0.474 & 0 & 0.402 \\
6 & 0.426 & 0.378 & 0.298 & 0.614 & 0.291 & 0 \\
\hline
\end{tabular}

(1)1, 'BRS Rubiflora'; 2, 'BRS Rosea Púrpura'; 3, 'BRS Roseflora'; 4, 'BRS Céu do Cerrado'; 5, 'BRS Estrela do Cerrado'; and 6, 'BRS Pérola do Cerrado'.

Table 7. Estimates of Pearson correlation coefficients among the calculated genetic distances based on categorical descriptors (qualitative and quantitative), quantitative morphoagronomic descriptors, and on RAPD and ISSR molecular markers.

\begin{tabular}{lcccc}
\hline Variables & $\begin{array}{c}\text { Categorical } \\
\text { descriptors }\end{array}$ & $\begin{array}{c}\text { Quantitative } \\
\text { descriptors }\end{array}$ & RAPD & ISSR \\
\hline Categorical $(\mathrm{n}=33)$ & - & $0.78^{* *}$ & $0.55^{*}$ & $0.66^{* *}$ \\
Quantitative $(\mathrm{n}=8)$ & & - & $0.15^{\mathrm{ns}}$ & $0.36^{\mathrm{ns}}$ \\
RAPD & & & - & $0.92^{* *}$ \\
ISSR & & & & - \\
\hline
\end{tabular}

**, *Significant at 1 and $5 \%$ probability, respectively, by the $t$ test.

morphoagronomic traits, is a way to prove the distinctness of a new cultivar in relation to other 
protected ones. Although DNA molecular markers, such as RAPD and ISSR, are not the official methodology to protect cultivars, they have proved to be effective for the characterization and quantification of the genetic variability of several plant species, and this is the reason why they have been used as an auxiliary tool (Faleiro, 2011; Brasil, 2016).

\section{Conclusions}

1. Categorical and quantitative morphoagronomic descriptors, together with the RAPD and ISSR molecular markers, are useful and allow of an adequate and complementary characterization of the passion fruit (Passiflora spp.) ornamental cultivars BRS Rubiflora, BRS Rósea Púrpura, BRS Céu do Cerrado, BRS Roseflora, BRS Estrela do Cerrado, and BRS Pérola do Cerrado.

2. The differentiation of ornamental passion fruit cultivars based on at least two categorical descriptors is possible, and cultivars with the same genetic basis in their genealogies show a cluster tendency.

3. The validation of descriptors used in the process of protection of passion fruit cultivars evidences the need to make adjustments, in order to increase its efficacy to accurately differentiate ornamental passion fruit cultivars.

\section{References}

ARAÚJO, F.P. de; SILVA, N. da; QUEIROZ, M.A. de. Divergência genética entre acessos de Passiflora cincinnata Mast com base em descritores morfoagronômicos. Revista Brasileira de Fruticultura, v.30, p.723-730, 2008.

BELLON, G.; FALEIRO, F.G.; JUNQUEIRA, N.T.V.; FUHRMANN, E. Variabilidade genética de genótipos elite de maracujazeiro, obtidos em programas de retrocruzamento envolvendo espécies silvestres e comerciais com base em marcadores RAPD. Bioscience Journal, v.30, p.1692-1697, 2014.

BELLON, G.; FALEIRO, F.G.; PEIXOTO, J.R.; JUNQUEIRA, K.P.; JUNQUEIRA, N.T.V.; FONSECA, K.G.; BRAGA, M.F. Variabilidade genética de acessos obtidos de populações cultivadas e silvestres de maracujazeiro-doce com base em marcadores RAPD. Revista Brasileira de Fruticultura, v.31, p.197-202, 2009.

BRASIL. Ministério da Agricultura, Pecuária e Abastecimento. Formulários para proteção de cultivares: Formulário 3 Espécies em regime de proteção: instruções de DHE e tabela de descritores mínimos. Available at: <http://www.agricultura. gov.br/vegetal/registros-autorizacoes/protecaocultivares/ formularios-protecao-cultivares/MARACUJA_OUTRAS_
SPP_FORMULARIO_16DEZ2008_P.doc.>. Accessed on: Dec. 292016.

BRS ESTRELA do Cerrado: primeiro híbrido de maracujazeiro ornamental do Brasil. Available at: $<$ http://www.cpac.embrapa. br/publico/usuarios/uploads/lancamentoornamentais/BRS\%20 Estrela\%20do\%20Cerrado.pdf>. Accessed on: Dec. 272016.

BRS PÉROLA do Cerrado: Cultivar de maracujazeiro silvestre com quádrupla aptidão: consumo in natura, processamento industrial, ornamental e funcional. Available at: $<$ http://www. cpac.embrapa.br/publico/usuarios/uploads/lancamentoperola/ foldertecnico.pdf $>$. Accessed on: Jan. 52015.

BRS ROSEFLORA: Híbrido de passiflora para uso como planta ornamental. Available at: <http://www.cpac.embrapa.br/publico/ usuarios/uploads/lancamentoornamentais/BRS\%20Roseflora. pdf $>$. Accessed on: Dec. 272016.

BRS RUBIFLORA: Híbrido de Passiflora para ornamentação de muros e pérgulas. Available at: $<$ http://www.cpac.embrapa. br/publico/usuarios/uploads/lancamentoornamentais/BRS $\% 20$ Rubiflora.pdf>. Accessed on: Dec. 272016.

CASTRO, A.P.G. de; FALEIRO, F.G.; CARVALHO, D.D.C.; FONSECA, K.G. da; VILELA, M. de F.; JUNQUEIRA, N.T.V.; CARES, J.E. Genetic variability of Passiflora spp. from commercial fields in the Federal District, Brazil. Ciência Rural, v.41, p.996-1002, 2011. DOI: 10.1590/S0103-84782011000600013.

CERQUEIRA-SILVA, C.B.M.; JESUS, O.N.; SANTOS, E.S.L.; CORREA, R.X.; SOUZA, A.P. Genetic breeding and diversity of the genus Passiflora: progress and perspectives in molecular and genetic studies. International Journal of Molecular Sciences, v.15, p.14122-14152, 2014. DOI: 10.3390/ijms150814122.

CERQUEIRA-SILVA, C.B.M.; SANTOS, E.S.L.; CONCEIÇÃO, L.D.H.C.S.; CARDOSO-SILVA, C.B.; PEREIRA, A.S.; OLIVEIRA, A.C.; CORRÊA, R.X. Genetic variation in a wild population of the 'sleep' passion fruit (Passiflora setacea) based on molecular markers. Genetics and Molecular Research, v.11, p.731-738, 2012. DOI: 10.4238/2012.March.22.3.

COSTA, J.L.; JESUS, O.N. de; OLIVEIRA, G.A.F.; OLIVEIRA, E.J. de. Effect of selection on genetic variability in yellow passion fruit. Crop Breeding and Applied Biotechnology, v.12, p.253260, 2012. DOI: 10.1590/S1984-70332012000400004.

CRUZ, C.D. GENES: a software package for analysis in experimental statistics and quantitative genetics. Acta Scientiarum. Agronomy, v.35, p.271-276, 2013. DOI: 10.4025/ actasciagron.v35i3.21251.

CRUZ, C.D.; REGAZZI, A.J.; CARNEIRO, P.C.S. Modelos biométricos aplicados ao melhoramento genético. 3.ed. Viçosa: Ed. da UFV, 2004. 480p.

FALEIRO, F.G. Aplicações de marcadores moleculares como ferramenta auxiliar em programas de conservação, caracterização e uso de germoplasma e melhoramento genético vegetal. In: FALEIRO, F.G.; ANDRADE, S.R.M. de; REIS JUNIOR, F.B. dos (Ed.). Biotecnologia: estado da arte e aplicações na agropecuária. Planaltina: Embrapa Cerrados, 2011. p.55-118.

FALEIRO, F.G.; FALEIRO, A.S.G.; CORDEIRO, M.C.R.; KARIA, C.T. Metodologia para operacionalizar a extração 
de DNA de espécies nativas do Cerrado visando a análises moleculares. Planaltina: Embrapa Cerrados, 2003. 6p. (Embrapa Cerrados. Comunicado técnico, 92).

FALEIRO, F.G.; JUNQUEIRA, N.T.V.; BRAGA, M.F.; PEIXOTO, J.R.; BORGES, R. de S.; ARAÚJO, S.C.B. de; ANDRADE, S.R.M. de; COSTA, A.M.; CASTELLEN, M. da S.; VAZ, A.P.A.; SOARES-SCOTT, M.D.; BERNACCI, L.C.; ANDRADE, G.A. BRS Estrela do Cerrado, BRS Rubiflora, BRS Roseflora: híbridos de maracujazeiro para uso como plantas ornamentais. In: FALEIRO, F.G.; FARIAS NETO, A.L. de; RIBEIRO JÚNIOR, W.Q. (Ed.). Livros e cultivares apresentados no II Encontro da Sociedade Brasileira de Melhoramento de Plantas - Regional - DF. Planaltina: Embrapa Cerrados, 2009. p.44-45.

IBRAFLOR. Instituto Brasileiro de Floricultura. Números do Setor: Mercado Interno: 2015: Mercado Interno 12.2014. Holambra: Ibraflor, 2015. Available at: <http://www.ibraflor.com/ ns_mer_interno.php>. Accessed on: Dec. 282016.

JESUS, O.N. de; OLIVEIRA, E.J. de; FALEIRO, F.G.; SOARES, T.L.; GIRARDI, E.A. Descritores morfoagronômicos ilustrados para Passiflora spp. Brasília: Embrapa, 2016. 122p.

JESUS, O.N. de; OLIVEIRA, E.J. de; SOARES, T.L.; FALEIRO, F.G. (Ed.). Aplicação de descritores morfoagronômicos utilizados em ensaios de DHE de cultivares de maracujazeirodoce, ornamental, medicinal, incluindo espécies silvestres e híbridos interespecíficos (Passiflora spp.): manual prático. Brasília: Embrapa, 2015. 45p.

MACHADO, C. de F.; JESUS, F.N. de; LEDO, C.A. da S. Divergência genética de acessos de maracujá utilizando descritores quantitativos e qualitativos. Revista Brasileira de Fruticultura, v.37, p.442-449, 2015. DOI: 10.1590/0100-2945-110/14.

NEVES, M.F.; ALVES PINTO, M.J. (Coord.). Mapeamento e quantificação da cadeia produtiva de flores e plantas ornamentais do Brasil. São Paulo: OCESP, 2015. 122p.

PAIVA, C.L.; VIANA, A.P.; SANTOS, E.A.; SILVA, R.N.O.; OLIVEIRA, E.J. de. Diversidade genética de espécies do gênero
Passiflora com o uso da estratégia WARD-MLM. Revista Brasileira de Fruticultura, v.36, p.381-390, 2014.

PEIXOTO, M. Problemas e perspectivas do maracujá ornamental. In: FALEIRO, F.G.; JUNQUEIRA, N.T.V.; BRAGA, M.F. (Ed.) Maracujá: germoplasma e melhoramento genético. Planaltina: Embrapa Cerrados, 2005. p.457-463.

SANTOS, E.A.; SOUZA, M.M.; VIANA, A.P.; ALMEIDA, A.A.F.; FREITAS, J.C.O.; LAWINSCKY, P.R. Multivariate analysis of morphological characteristics of two species of passion flower with ornamental potential and of hybrids between them. Genetics and Molecular Research, v.10, p.2457-2471, 2011a. DOI: 10.4238/2011.October.13.3.

SANTOS, E.A.; VIANA, A.P.; FREITAS, J.C.O.; SOUZA, M.M.; PAIVA, C.L.; RODRIGUES, D.L.; TAVARES, R.F. Phenotyping of Passiflora edulis, $P$. setacea, and their hybrids by a multivariate approach. Genetics and Molecular Research, v.13, p.9828-9845, 2014. DOI: $10.4238 / 2014$.November.27.10.

SANTOS, L.F. dos; OLIVEIRA, E.J. de; SILVA, A. dos S.; CARVALHO, F.M. de; COSTA, J.L.; PÁDUA, J.G. ISSR markers as a tool for the assessment of genetic diversity in passiflora. Biochemical Genetics, v.49, p.540-554, 2011b. DOI: 10.1007/ s10528-011-9429-5.

SINGH, D. The relative importance of characters affecting genetic divergence. Indian Journal of Genetics and Plant Breeding, v.41, p.237-245, 1981.

SOUSA, A.G.R.; SOUZA, M.M.; MELO, C.A.F.; SODRÉ, G.A. ISSR markers in wild species of Passiflora L. (Passifloraceae) as a tool for taxon selection in ornamental breeding. Genetics and Molecular Research, v.14 p.18534-18545, 2015. DOI: 10.4238/2015.December.23.41.

VIANA, A.J.C.; SOUZA, M.M.; ARAÚJO, I.S.; CORRÊA, R.X.; AHNERT, D. Genetic diversity in Passiflora species determined by morphological and molecular characteristics. Biologia Plantarum, v.54 p.535-538, 2010. DOI: 10.1007/s10535-0100094-z.

Received on June 21, 2016 and accepted on January 25, 2017 